Kohl: a Journal for Body and Gender Research

Vol. 4, No. 1 (Summer 2018)

\title{
What Stories Do to our Hearts
}

\author{
Zahra Abdallah
}


When letters begin to form on our tongues to formulate our stories through storytelling, hearts lose their numbness. These words carry feelings and memories which, while not mine, combine and intertwine to tell me that pain unites us all.

Since I have started working with the "BuSSy Project," I have heard a lot of stories, some of which, although similar to mine, were told by another heroine, and others that seemed remote if not for the experience that brought us closer.

Al-Makan Dah ("That Place") is a temporal space that reflects on the stories of 11 women. The show was the result of a three-month workshop organized by BuSSy in collaboration with the Association for the Care for the Children of Prisoners and a group of former inmates. The show tells stories about life inside prison, social stigma, and its impact on former prisoners. The show's aim was for the audience to experience the place through a simulation of the prison through stories.

During the three months of workshops, I worked on compiling, listening to, and recording stories. We do not come out of the workshops the same as we entered, since we engage with the stories and their tellers. We leave the workshops with souls borne with mixed feelings that do not return us to our previous selves, as our eyes widen to see areas unseen before, with our hearts filled and flowing with love.

At that time, I had never met with prisoners or dealt with prisons. I had acquired all my information about prison and prisoners from books and television. Acquaintance, on the other hand, was fundamentally different from the stereotypes we were fed. Coexistence enables one to hear the hidden and silenced dimension of the story, to empathize with its narrator regardless of prejudices - and this is exactly what happened to me. The full picture is never one-dimensional, as we are accustomed to see in the media. That one-dimensional perception is due to the lack of awareness and dominant institutions' control over discourse. The workshop made me see other dimensions of an image bearing guilt and atonement in its appearance, and mercy or a sacrifice or a cry for existence and merit within. Everyone has the right to find the support they need unconditionally, whether they are labeled "criminal" or "innocent."

Government systems use the prison as a punitive institution to deter citizens from wrongdoings, as if one were thrilled to oppress the other whenever the opportunity presented itself. The penal system does not provide reform; healthcare is not available for prisoners, and their physical and mental illnesses increase and do not fade away at the time of the release. The deterioration of the health situation affects the quality of life of former inmates after the termination of their sentence, especially when it comes to women, as their health is considered marginal both outside and behind prison bars. Most of the participants in the workshop complained of osteoporosis and joint pain, attributing them to the period they spent in prison.

The participants told us that they had not lost their health and reputation alone in prison; one of them had lost her home and custody of her daughter. Her husband divorced her once she was arrested, although a small fine would have been enough to solve her problem. But the person she considered closest to her abandoned her to serve 7 months in jail and lose all she had. A second woman told me that she left the 
prison after serving her sentence, only to find out that her husband had married a second time and deprived her of her son. A third said that she was proved innocent after serving five years in prison, an entire five years during which she lost her freedom and her home so she could pay the lawyer's fees. In prison, women inmates not only lose their lives, but also their health, their self-confidence, and their ability to reintegrate into their societies. Society does not accept them as "good citizens;" it reminds them of their experience all the time when they search for work or marriage or other social matters.

I remember the moment when one of the participants hugged me and told me that in the space BuSSy created - that space only, she did not feel branded. She was as human as everyone else, while society kept on punishing her even after she served her "actual" punishment. Another one told me that all she wanted was to live in peace with her children without being apologetic all the time. A third did not want to see the looks of pity and regret ever again in the eyes of those around her. A fourth recounted her creative ways of hiding her story from her sons-in-law to save her daughters from the burden of carrying that stigma with her:

"I feel that my children are bothered by me because I was imprisoned

They do not treat me like their mother but like a random person

And my sisters tell me: 'Yeah, you've been to prison'

'Your style is prison style'

And I do not even curse or use swear words at all

I feel that a lot of people are afraid of me."

They all want life without stigma. One of the participants told me that she was devoting all her efforts to winning the cause of rehabilitation:

"I will do a rehabilitation act for my children, but I will not return to my husband

$\mathrm{He}$ is the reason behind all the trouble I am in

Every time l'd say I need something, he'd say: 'Make it work'

I was vagabonded with my children"

When the time came to show their stories to the audience, we were looking forward to hearing their views on the performance. The following day, we took them to the venue and read the public comments to them. There were mixed feelings and endless tears in eyes that had long resisted years of grief and pain, wanting to feel that there are people who would excuse them and be touched by their stories and their humanity, people who would understand the humanity of succeeding at times and failing at others. They wanted people to recognize their weakness or strength and to accept them both. This recognition might help them get rid of feeling constantly criminalized and stigmatized. At first glance, these women are the mistresses of oppression and victimhood, but after hearing their stories, one understands that they are heroines of real battles that they fight singlehandedly and unremittingly.

The stories intersect and diverge from each other, but one thing remains constant; they carry us to other worlds in which spending time had seemed impalpable. El Makan Dah moved us to a different place in art. It 
gave resonance to stories that were going to be buried as soon as the women came out of the prison gate, as they would try to escape the memory of the bitter experience.

BuSSy is an artistic project aimed at creating a free space for women and men in Egypt to tell personal experiences that are often forgotten in the society. It also documents and presents real stories in the form of theater performances in different communities in Egypt.

BuSSy tries to resist societal constraints through theater. Women and men stand on stage in different Egyptian communities and cities to share their stories about harassment and rape, discrimination, honor crimes, forced marriage, circumcision, motherhood, domestic violence, child sexual abuse, sexual assault and other topics that the society forbids talking about. The project organizes workshops for individuals from different backgrounds and ages, and supports and encourages them to tell their personal stories on stage.

For more information about the BuSSy project: www.bussy.co

Facebook: TheBuSSyProject 